UDC 821.161.2-3.09(092)

\title{
Oksana Blashkiv
}

\section{INTELLECTUALS IN THE FACE OF HISTORICAL TURMOIL: THE REVENGE OF THE PRINTER BY STANISLAV ROSOVETSKYJ AS ACADEMIC FICTION}

Even though the academic novel centered on the life of a university professor [17, p. 561-562] is primarily viewed as a phenomenon of English and American literary traditions $[12 ; 7 ; 8 ; 15]$, recent studies show its presence in other literary traditions [6], including contemporary Ukrainian literature [1;2]. Oksana Zabuzhko's "Fieldwork in Ukrainian Sex" (1996) may be treated as a pioneering text within the genre and is the one which received the most publicity. Other novels of this kind published in the following decades, like "The University" (2007) and "Kaleidoscope" (2009) by Igor Yosypiv, and "Drosophila over a Volume of Kant" (2010) by Anatoliy Dnistrovyj, "A Quarter to Ten" (2013) by Yuri Makarov, "The Department" (2017) by Daryna Berezina are still awaiting discovery by readers and critics alike. Their generic characteristics vary from the Bildungsroman, the career novel and the initiation novel to the historical adventure and mystic novel, which suggests an ongoing shaping of the genre in Ukrainian literature. In this respect, "The Revenge of the Printer" (2009) by Stanislav Rosovetskyj (I), which is generically perceived as a historical, adventure, detective, and mystic novel featuring an academic as its protagonist, is a vivid example of the Ukrainian invariant of the academic novel. Moreover, the protagonist - a history professor - is presented in unique historic circumstances and in a peculiar cultural climate which makes him an interesting character for study within academic discourse.

Like a classic academic novel, "The Revenge of the Printer" covers several months of a professor's life. However, in the novel the time of action is conditioned by two plot lines. One of them is set in the summer of 1991 and centers on Shavla Bulatovich Bukviani, the only doctor of sciences at the Ivan Fedorov Museum in Lviv. The second plot line (C) Oksana Blashkiv, 2019 https://doi.org/10.34142/2312-1076.2019.3.93.01 
centers on the figure of the first East-European book-printer Ivan Fedorov (also known as Iwan Fedorowicz of Mocsow), who was also directly linked to the establishment of the printing press at the Ostrih Academy (1576-1636), the first university on the territory of present-day Ukraine, founded by Prince Konstantyn-Vasyl Ostrozky. This line is mainly based on the research that went into reconstructing fragments of Fedorov's biography. The two plot lines are connected by the mysterious waking of Fedorov's ghost during the unearthing of his remains from the grave at St. Onuphrius Monastery in Lviv under the supervision of Shalva Bukviani. The novel begins with the scene of the exhumation of Fedorov's remains. When the coffin is lifted, however, the burial plate shows a different name. This forces those present at the event to question the identity of the remains and to collect the bones into a box to be kept under the table in one of the Monastery's rooms for the time being (II). Meanwhile, the ghost of Fedorov, bound to the bones, observes his 'descendant' Bukviani and his colleagues.

St. Onuphrius Monastery is the main topos of the novel. Owing to the fact that the university as an educational institution evolved from church schools and usually housed so-called "brethren schools" having the same function in Ukrainian monasteries, it may be treated as a variant of the university campus, a proper setting for an academic novel. St. Onuphrius Monastery is also an actual historical landmark and its history is important for the reader since it provides a necessary historic and cultural context. Dating back to the thirteenth century, the times of the founder of Lviv, Leo I of Halych, in the late sixteenth century St. Onuphrius Monastery opened its doors to Ivan Fedorov and his printing press. Here, a famous book entitled "The Apostle" was printed in 1574. It is highly valued due to its etchings, the city's and Fedorov's coat of arms on the title page in particular. Its Afterword is regarded as the first example of memoirist literature in Old Ukrainian [11, p. 38]. In 1583, Ivan Fedorov was buried in St. Onuphrius Monastery. During Soviet times (in 1975) the monastery was turned into a museum of book-printing known as the Ivan Fedorov Museum, where the Bukviani plot line develops. 
In the novel, Fedorov is mostly referred to as Pershodrukar (Ukr.: "The First Book Printer"), while Bukviani is a Georgianized word derived from the root of the word "bukva" (letter), which symbolically links the two through time by their apprenticeship. However, the juxtaposition of these characters does not work to the advantage of Bukviani: he is treated ironically, even satirically. Shalva Bulatovich Bukvianiwas a Georgian by birth. His interest in book-printing derived not from inborn curiosity or love of books but unwillingness to return to his native village in the Caucasus. The academic work seemed as the most certain path to upward social mobility for him, which is why he appreciates the fact that he now lives in the center of Lviv, historically the district of residence for the local Ukrainian (!) elite. However, in order to conform to the state ideology, Bukviani has to follow the Moscow guidelines in his research and look for Russian influences on the history of Ukrainian book-printing. This leaves him with narrow possibilities of talking about books as artifacts, comparing fonts and decorations, and leaving out the content. Digging up Fedorov's grave presents him with a chance to write the probably first meaningful academic article to be published in Moscow, in the journal "Fedorovskije chtenia" (The Fedorov Readings). However, the unidentifiable remains and the change of political order rob him of this long-awaited chance for academic glory.

Like the protagonists of Anglo-American academic novels who strive to obtain the position of Master of college or Dean of the school, Bukviani's secret dream was to become a faculty member and Full Professor at Lviv University. To reach his goal, he started as an adjunct professor supervising post-graduate theses. Unlike many professor protagonists who hid their academic impotence behind excessive love affairs, Bukviani did not hide behind the love affair with his student Larysa: he was the true author of a dissertation proposal, annually academic outputs, and thesis chapters written under her name, the reason for this being a rigorous control Soviet academic institutions had over students' and supervisors' academic progress. Larysa, on the other hand, put up with him to secure her future by obtaining a degree and possibly also by marrying him. With the end of her post-graduate studies, her affair ended as well as her hope 
for a $\mathrm{PhD}$. Now that the country had declared independence, she foresaw the substitution of the Soviet ideology by a new nationally-oriented one, which would bring nothing but a flood of incompetent demagogues into the academic world. Since economic comfort could not be secured by an academic degree anymore, she married a foreigner to leave the country. Bukviani, however, remained blind towards the obvious tendencies at work, interpreting them as transient and irrelevant against the background of the gains the Independence promised.

Larysa's predictions about future nationalist scholarship are paralleled by observations of Fedorov's ghost. The institution which carries his name and its staff do not look appealing at all: strangely under-dressed people come every day to a small room solely to share gossip and have tea, opening the old printed books on their tables for camouflage; when they start an academic discussion, it often turns into 'history mythmaking' loosely based on historical facts, in the spirit of the Soviet method of re-writing history, or a contest of mutual accusations in incompetence. An apogee of their academic achievement is an open letter addressed to (still Soviet) Verkhovna Rada URSR (the highest legislative branch of the Ukrainian Republic) with a demand "to disband the Ivan Fedorov Museum established as an act of groveling in front of the 'big brother' $<\ldots>$ which now is a monument to Ukraine's Russification" [14, p. 44]. Bukviani turns out to be the only one opposing the absurdity of the plea and the only one refusing to sign the petition: he seems to be the only historian who understands the true role of Fedorov in Ukrainian history and does not waver in the face of the changing political narrative.

It is worth mentioning that juxtaposing Fedorov, a historical figure, and Fedorov, a Soviet cultural icon, Rosovetsky plays with or puzzles the reader, requiring from him deep rather than merely general knowledge of sixteenth-century Ukainian history and of contemporary historical discussions of it. This historical and historiographic dimension adds a touch of academic intertextuality, something academic novels are known for. Ivan Fedorov (1510-1583) as a historical figure, i.e. the East-European Gutenberg (as we would refer to him today), lived in the sixteenth century and is known for his book-printing on the territory of Muscovy (1283-1547, 
the Grand Duchy of Moscow), the state preceding the early modern Tsardom of Russia, and the Grand Duchy of Lithuania (1236-1795), which in 1566-1795 was part of the Polish-Lithuanian Commonwealth. The books Fedorov printed during his lifetime were religious books in Church Slavonic: the "Apostolos" of 1563 (publ.in Moscow), "Didactic Gospel" (1569), "Psalter" (1570), the "Apostolos" of 1574, the "Primer" (1574) and the Ostrih Bible (1581) [5]. In Soviet historiography Fedorov was a cultural icon associated with pioneering attempts at book-printing and the spreading of knowledge throughout the territory of the Soviet Union, hence his widely popularized name Pershodrukar. The Soviet people mostly knew him as "a famous son of the Russian nation who worked for the cause of Ukrainian culture" [16, p. 45] and a printer of the Cyrillic Primer (Azbuka). Since the brotherhood of the three East-Slavic peoples in the Soviet Union was one of the pillars sustaining the Soviet Union, Ivan Fedorov, who in the sixteenth century lived and printed books on the territory of present-day Russia, Belarus, and the Ukraine, was of paramount cultural importance as a symbol of the "primeval unity" of these nations (pradavnia jednist narodiv), completely disregarding the fact that in the sixteenth century the only identity people lived by was religious, and for Fedorov this was Orthodox Christianity.

In the novel, unlike in the Soviet narrative, the religious does meet with the national. That, however, involves another historic figure beside Fedorov, i.e. Konstantyn-Vasyl Ostrozky (1526-1608). In his fictional memoirs, Fedorov appears as a highly educated person, proud of his craft and endowed with the sense of a mission to print the whole Bible in Church Slavonic translation in order to unite the whole Orthodox world. Moreover, through the character of Fedorov, Rosovetsky links Bible printing with Konstantyn-Vasyl Ostrozky's visions of statehood. Ostrozky is also known in history as a descendent of St. Volodymyr (who christened Kyivan Rus in 988) and "the protector of Orthodoxy" [9, p. 13]. In the late sixteenth century he was the richest person in Europe (his annual budget is estimated by historians to have equaled two annual budgets of Kingdom of Poland when it was not at war). He owned almost the entire territory of present-day Ukraine and had his own army to protect 
it from the Tatar raids and Russian invaders. To realize his state-building ambition, a Bible in Church Slavonic was needed as a means of both education and propaganda against Catholicism. Historians believe that for this purpose Prince Ostrozky founded a university (Ostrih Academy) in the 1570 s, which also had a printing press and an international community of translators who finished translation of the whole Bible into Church Slavonic and printed it in 1581. It is not accidental then that this is the Bible used by Ukrainian presidents to take an oath on the day of their inauguration.

In the novel, Oztrozky advocates the union of the Orthodox and Catholic branches of Christianity proclaimed on the Council of FerraraFlorence (1438-1445). Fedorov's mission given by Ostrozky was to deliver Church Slavonic script to Venice for Catholics to print new religious books in national languages as a means of ecumenical propaganda. Ostrozky's cooperation with the Pope was supposed to provide people on his lands with a national identity and to bring about the eventual establishment of Ukraine as an independent state. The fictional Fedorov was highly pessimistic about it: fulfilling Ostrozky's mission, he reached Vienna, Rome, Bologna, Venice with all their cultural and material riches, only to realize that Orthodox Eastern Europe would never be an equal partner of Catholic Europe; hence, decisive separation would work for the Eastern Slavs, not a union. Fedorov's untimely death would prevent him from seeing the effects of his lifetime work, i.e. the Church Slavonic Bible printed with Prince Ostrozky's financial support.

In the novel, Ostrozky's hypothetical statehood ambitions are paralleled by the proclamation of Ukraine's Independence in August 1991. The speech Ostrozky gives to Fedorov about Ukrainians being people of a blurred, ever-adjusting identity, bred by decades of compromising with the Polish to the West and Muscovites to the East [14, p. 134-136], ironically echoes people's wavering in the early 1990s. The Museum's staff - true intellectuals and representatives of local intelligentsia - are concerned by the necessity to define everything Ukrainian in the summer of 1991. In the name of Independent Ukraine, some of them try to look for the roots of Ukrainian identity in pre-Christian times, others try to find 
a family member whose repressed-by-the-Soviets life story could help them improve their own, some write anonymous defamations of their colleagues, while others make attempts to profit in the times of change by promoting themselves in the academic world at somebody else's expense. Unlike Ostrozky, the late-twentieth century elite has no statehood ambitions, but is concerned with private well-being.

As readers of academic novels would expect, in times of crisis the academic institution turns from being a place of petty politicking into a battle field. Having separated themselves politically from Ivan Fedorov's heritage, the Museum staff turn against each other in order to keep their job despite an ongoing downsizing process. Bukviani's academic reputation is under attack: he is accused of writing a dissertation for his wife. Bukviani is about to lose his job with a Museum already reorganized into a Ukrainian Institute of Book Printing, but he is given a choice - to quit or to ghost-write two dissertations: a doctoral dissertation for Sapogov, an old director in a new institution who wants to ensure his administrative position, and a candidate dissertation for Irochka, Sapogov's fiancée and a former lover of Bukviani. As is the case with classic academic novels, the protagonist faces a choice whether to stay with the institution or to quit [4, p. 591]. The psychological breakdown he goes through prompts Bukviani to go with a third option: to attempt to murder Sapogov. The graveness of the situation is diminished by the last-minute rescue of Sapogov by Fedorov's ghost, who saves not only the man's life, but also the soul of Bukviani, who subsequently converts to the faith of his forefathers. Bukviani's life turns from being successful and promising into a lost cause within three months; the only hope is spiritual. However, both the Book-printer and Bukviani understand that a boring life with boring love affairs is what awaits the latter in the years to come.

In his monograph "The Intellectual as Hero in 1990s Ukrainian Fiction" Mark Andryczyk introduces three leading types of intellectuals represented in the Ukrainian literature of the period - the Swashbuckling Performer, the Ambassador to the West, the Soul-Sick. If the first two are shaped by the euphoria that overwhelms people after Independence is proclaimed, the last one derives from the chaos settling in simultaneously. 
Andryczyk defines the Soul-Sick as "a disillusioned hero who is formed by the chaos engulfing Ukrainian cultural life in the 1990s" [1, p. 13]. Rosovetsky's novel captures the moment of a moral, professional, and psychological rupture brought about by the dissolution of the Soviet Union, which affected thousands of Soviet scholars, particularly from the field of the Humanities. In the novel, Bukviani is portrayed during the early stages of the Soul-Sick identity formation.

In Anglo-American academic novels, since Kingsley Amis's "Lucky Jim" (1954), satire has remained an essential force driving the genre [8, p. 7]. No wonder that writers' and readers' attention has focused on institutions and characters chosen for their potential for ridicule and for the manner in which this is achieved [13, p. 249]. The fact that in Rosovetsky's novel the Museum of Book Printing becomes the institution to be ridiculed, on the one hand, speaks to the crisis of values symbolically embodied in the image of the monastery, and, and on the other, to the crisis of knowledge symbolically presented by the image of the book. The opportunism of Soviet academics, guardians of cultural heritage, begs a question about the historical narrative. Based on the example of Soviet narrative, constructed around the figure of Ivan Fedorov to suit the needs of state ideology, the author addresses the issue of cultural memory which shapes the nation's identity, especially in the times of the country's establishing its independence. The inability of Bukviani to influence the situation parallels the helplessness of thousands of Soviet academics who in the turbulent 1990s could not cope with an aggravating crisis, both cultural and political. The reformation and restructuring of the Museum ('the microcosm of society at large' (D. Lodge)) eloquently illustrates the idea as to what awaits the country and its cultural heritage in the future.

Along with the issues of national and professional identity, academic excellence and ethics, regional history and national mythmaking, through the figure of Ivan Fedorov and the scholar-protagonist the novel addresses issues of cultural memory. The fact that the novel published in late 2000 s treats history as its main character seems highly symptomatic: the distance of over fifteen years from the events of 1991 allows a reassessment of achievements and a redefinition of goals. The fact that in the early 
1990s Fedorov disappeared from public space and cultural discourse and that in 2003 he was officially stripped by UNESCO of the honour of being the First Book-printer, at the request initiated by the Russian Federation [10, p. 5-6], testifies to random rather than thoughtful politics of cultural memory in the Ukraine. By its own example, the novel shows that literature can and does shape cultural memory and that the emerging genres in contemporary Ukrainian literature, such as the academic novel, may be most productive in this process. The Ukrainian invariant of the academic novel with a stronghold in history enriches world literature and creates a promising field for further research.

\section{Endnotes}

(I) Stanislav Rosovetsky (b. 1945) is a Professor of Old Ukrainian and Old Russian literatures and folklore at Taras Shevchenko National University. Along with numerous academic publications and textbooks, he authored several novels and plays, which were nominated for awards. His novel "The Revenge of the Printer" received a highest award during the Days of Science Fiction in Kyiv in 2010. In tune with the authors of Anglo-American academic novels, who were university professors, Rosovetsky academic biography both speaks to readers' expectations and highlights the novel's generic template.

(II) The exhumation and identification process is actually a historical fact. Fedorov's bones were kept in boxes till 2013, when the Forensic Department of Wroclaw University finally identified them as probably being Fedorov's. In December 2014, his remains were re-buried in the same grave they were taken out of in 1991.

\section{References}

1. Andryczyk, M. The Intellectual as Hero in 1990s Ukrainian Fiction. Toronto: University of Toronto Press, 2012.

2. Blashkiv, Oksana. "Vagaries of (Academic) Identity in Contemporary Fiction." Journal of Education Culture and Society, 9/1 (2018): 151-160. Accessed 26 January 2019. URL: https://jecs.pl/index.php/jecs/article/ view/10.15503jecs 20181.151.160

3. Blaškiv, Oksana. "Istoričeskie perepetii skvoz prizmu ukrainskogo universitetskogo romana [Historic Vicissitudes through the Prism of the Ukrainian Academic Novel]." Conversatoria Litteraria, XII (2018): 135-149. Accessed 25 November 2019. URL:https://czasopisma.uph.edu.pl/index.php/ testowe2/article/view/638 
4. Dalton-Brown, Sally. Is There Life Outside of the Genre of the Campus Novel? Academic Struggles to Find a Place in Today's World. "The Journal of Popular Culture" 41/ 4 (2008): 591-600.

5. Fedorovych (Fedorov), Ivan, in: Internet Encyclopedia of Ukraine. Accessed 25 November 2019. URL:http://www.encyclopediaofukraine.com/ display.asp? linkpath=pages $\% 5 \mathrm{CF} \% 5 \mathrm{CE} \% 5 \mathrm{CFedorovychFedorovIvan.htm}$

6. Fuchs, Dieter, Klepuszweski, Wojciech. The campus novel: regional or global? Leiden-Boston: Brill Rodopi, 2019.

7. Kramer, John E., Ron Hamm and Von Pittman. The American College Novel: An Annotated Bibliography. Lanham, Maryland: Scarecrow Press, 2004.

8. Moseley, Merritt. (Ed.) The Academic Novel: New and Classic Essays. Chester Academic Press, 2007.

9. Myts'ko, Ihor. “Ostoz'ka sloviano-greko-latyns'ka academia [The Ostroh Slavic-Greek-Latin Academy].” Ostroz'ka davnyna: Dzherela i materialy 1 (1995): 59-68.

10. Myts'ko, Ihor. Ivan Fedorov: zhyttia v emihracii [Ivan Fedorov: the Life in Immigration]. Ostroh: Natsionalnyj universytet "Ostroz'ka Akademia", 2008.

11. Nemirovskyj, Yevgenij. Ivan Fedorov i yeho epokha. Entsyklopedia [Ivan Fedorov and His Epoch]. Moskva: OOO "Izdatelstvo "Entsyklopedia", 2007.

12. Proctor, Mortimer R. The English University Novel. Berkeley and Los Angelos: University of California Press, 1957.

13. Robbins, Bruce. What the Poster Saw: On the Academic Novel. In: English, James F. (Ed.). A Concise Companion to Contemporary British Fiction. Malden: Blackwell Publishing Ltd 2006, pp. 248-266

14. Rosovetsky, Stanislav. Pomsta Pershodrukaria [The Revenge of the Printer]. Kyiv: Zelenyj pes, 2009.

15. Showalter, Elaine. Faculty Towers. The Academic Novel and Its Discontents. Philadelphia: University of Pennsylvania Press, 2005.

16. Vydashenko, Maria, Isayevych Jaroslav, Matsyuk Orest. Mistsiamy Ivana Fedorova na Ukraini: Putivnyk [Places of Ivan Fedorov in Ukraine: a Guidebook]. Lviv: Kameniar 1982.

17. Williams, Jeffrey J. The Rise of the Academic Novel. "American Literary History" 24/3 (2012): 561-589.

18. Womack, Kenneth. Academic Satire: The Campus Novel in Context. In: Shaffer, Brian W. (Ed.). A Companion to the British and Irish Novel 19452000. Blackwell Publishing 2005, pp. 326-339. 


\section{Анотація \\ Оксана Блашків. Інтелектуали перед викликами історії: «Помста Першодрукаря» Станіслава Росовецького як університетський роман}

3 середини XX століття в англомовному літературознавстві склалася потужна традиція осмислення жанру університетського (академічного) роману. У англо-американській традиції цей жанр опирається на відображення життя професорів, тому художня дія часто виноситься за межі кампусу і стосується, в основному, їх особистого життя та побуту. Не менш важливою ознакою академічних романів є яскрава сатирична лінія, яка виразно та експресивно забарвлює їх фабули. Образ університету в академічному романі постає як «мікрокосмос суспільства в цілому». Хоч в сучасній українській літературі цей жанр ще тільки формується, уже можна стверджувати про зростаюче число текстів, котрих можна віднести до жанру університетського роману. Опираючись на основні характеристики жанру університетського англомовного роману, авторка пропонує аналіз роману «Помста Першодрукаря» Станіслава Росовецького як українського інваріанту академічного роману. Наявність у романі двох чітко маркованих сюжетних ліній, що відбуваються у 1991 році та у 1580-х роках, об’єднаних топосом Онуфріївського монастиря у Львові та постаттю друкаря Івана Федорова, дозволяє звернутися до теми ролі інтелектуалів в період складних історичних змін, зокрема ролі радянських вчених під час здобуття Україною незалежності у 1991 році. Вибір Музею книгодрукарства, закритого осередку на зразок університету, об'єктом сатири, а його старшого наукового співробітника, доктора наук Шалви Буквіані - протагоністом, котрий стоїть перед вибором піти на компроміс з сумлінням чи покинути дану інституцію, однією 3 сюжетних ліній роману, дозволяє розглядати роман в контексті університетського роману. Особливу увагу також приділено образу Івана Федорова, художня біографія котрого у романі постає як реконструкція альтернативної до радянського образу Першодрукаря біографії, що спираються на сучасні дослідження українських істориків. Завдяки цій постаті Федорова людини Ренесансу, образ сучасного вченого постає як образ «хворої душі» (М. Андрейчик), здрібнілої людини радянської культури кінця ХХ століття, неготової заангажуватися в політичну діяльность чи впливати на збереження культурної спадщини в рамках нової суспільної формації.

Ключові слова: університетський роман, інтелектуал, історія, Іван Федоров (Федорович), Станіслав Росовецький, «Помста Першодрукаря». 
14 Наукові записки ХНПУ ім. Г.С. Сковороди. Літературознавство, 2019, вип. 3(93)

\section{Аннотация \\ Оксана Блашкив. Интеллектуалы перед вызовами истории: «Месть Первопечатника» Станислава Росовецкого как университетский роман}

C середины XX века в англоязычном литературоведении сложилась мощная традиция осмысления жанра университетского (академического) романа. В англо-американской традиции этот жанр основан на отражении жизни профессоров, поэтому художественное действие часто выносится за пределы кампуса и касается их личной жизни и быта. Не менее важной чертой академических романов является яркая сатира, отчетливо и экспрессивно окрашивающая их фабулы. Образ университета в академическом романе предстает как «микрокосмос общества в целом». Хотя в современной украинской литературе это лишь формирующийся жанр, уже можно утверждать о растущем числе текстов, которые можно отнести к жанру университетского романа. Опираясь на основные характеристики жанра англоязычного университетского романа, автор анализирует роман «Месть Первопечатника» Станислава Росовецкого как украинский инвариант академического романа. Наличие в романе двух четко маркированных сюжетных линий, развивающихся в 1991 году и в 1580-х годах и объединенных топосом Онуфриевского монастыря во Львове и фигурой печатника Ивана Федорова, позволяет обратиться к теме роли интеллектуалов в период сложных исторических изменений. На жанровом уровне роман можно рассматривать как университетский, поскольку главным персонажем является доктор наук, старший научный сотрудник Музея книгопечатания (закрытая, выступающая объектом сатиры институция сродни университету), стоящий перед выбором - пойти на компромисс с совестью или покинуть данную организацию. Особое внимание уделено образу Ивана Федорова, биография которого, опирающаяся на современные исследования украинских историков, предстает в романе как художественная реконструкция, альтернативная советской версии биографии Первопечатника. Благодаря фигуре Федорова - человека Ренессанса, образ современного ученого выступает как образ «больной души» (М. Андрейчик), измельчавшего человека советской культуры конца ХХ века, не готового отстоять сохранение культурного наследия во времена общественно-политических изменений.

Ключевые слова: университетский роман, профессор, интеллектуал, история, Иван Федоров (Федорович), Станислав Росовецкий, «Месть Первопечатника». 


\section{Summary}

Oksana Blashkiv. Intellectuals in the Face of Historic Turmoil: "The Revenge of the Printer" by Stanislav Rosovetskyj as Academic Fiction

Since mid-twentieth century the academic novel has been treated in English literary criticism as a separate literary genre centered on the life of professors. Often the action takes place on and outside of campus, revealing the professors' private concerns. Satire is a characteristic feature of academic novels, which usually drives the action. In these novels university appears as a "microcosm of society at large." Even though the academic novel is an emerging genre in Ukrainian literature, there are texts which fall into this category. In the article the author analyzes "The Revenge of the Printer" by Stanislav Rosovetskyj as academic fiction. The novel has two plot lines, one of which is set in late 1580s in the times of Ivan Fedorov, another is set in the summer of 1991. The plot lines are joined by the setting, which is St. Onuphrius Monastery in Lviv, which in the twentieth century was turned into the museum of book-printing. The novel has the following features of the academic fiction: the main setting and the object of satire is the Ivan Fedorov Museum, a cloistered institution like the university campus; the protagonist Shalva Bukviani is an academic and a professor of history facing the choice to leave the institution or to conform to the changing ideology. Collectively, these characteristics allow to define the main theme as the role of individual in the times of historical turmoil. Special attention is paid to the image of Fedorov, whose life in the novel is portrayed as a literary biography, based on research of contemporary Ukrainian historians alternative to the Soviet narrative. Due to the image of Fedorov as "Renaissance man" in the novel, the image of contemporary scholar appears as Sick Soul (M. Andryczyk), "a small Soviet man" unable to engage in protection of cultural heritage in the time of sociopolitical change.

Keywords: academic novel, intellectual, history, Ivan Fedorov (Fedorovych), Stanislav Rosovetskyj, "The Revenge of the Printer".

\section{Інформація про автора}

Блашків Оксана Вірославівна - доктор філософії (кандидат філологічних наук); ад'юнкт в Інституті мовознавства і літературознавства, Університет природничо-гуманістичний в Сєдльцах; вул. Конарського 2, м. Сєдльце, 08-110, Польща; e-mail: oksana.blashkiv@uph.edu.pl; https://orcid.org/00000002-3607-9895 